\title{
Effects of age and sex on blood biochemistry of Dorper lambs
}

\section{Influência das faixas etárias e do sexo sobre variáveis bioquímicas sanguíneas de cordeiros da raça Dorper}

\author{
Rebecca Espírito Santo da $\mathrm{Cruz}^{1 *}$; Fernando Melo Rocha²; \\ Cassius Vinícius Barbosa Sena²; Pablo Gomes Noleto ${ }^{3}$; \\ Ednaldo Carvalho Guimarães ${ }^{4}$; José Antônio Galo ${ }^{5}$; Antonio Vicente Mundim ${ }^{6}$
}

\begin{abstract}
The purpose of this study was to evaluate the physiological variations and influence of age group and sex on biochemical variables of 32 male and female Dorper sheep at the age of 15 to 121 days. Four blood samples were collected from each animal, at monthly intervals, totaling 128 samples. Biochemical variables determined in each sample were total protein (TP), albumin (ALB), globulin (GLB), albumin/ globulin ratio $(\mathrm{A} / \mathrm{G})$, glucose $(\mathrm{GLU})$, triglycerides $(\mathrm{TG})$, total cholesterol (tCHOL), high density cholesterol carrying lipoproteins (HDL-C), low density cholesterol carrying lipoproteins (LDL-C), very low density cholesterol carrying lipoproteins (VLDL-C), urea, creatinine (CRE), total calcium $(\mathrm{Ca})$, ionized calcium $(\mathrm{Ca})$, phosphorus $(\mathrm{P})$, calcium/phosphorus ratio $(\mathrm{Ca} / \mathrm{P})$, magnesium $(\mathrm{Mg})$, sodium $(\mathrm{Na})$, potassium $(\mathrm{K})$, chloride $(\mathrm{Cl})$, alanine aminotransferase (ALT), aspartate aminotransferase (AST), gamma-glutamyl transferase (GGT) and alkaline phosphatase (ALP). The results were obtained in four moments according to age: M1 - sheep from 15 to 30 days, M2 - sheep from 45 to 61 days, M3 - sheep from 74 to 90 days and M4 - sheep from 105 to 121 days. Comparing the values of the biochemical variables among the four age groups studied a significant difference $(p<0.05)$ was observed in the concentrations of all the variables evaluated except for $\mathrm{Na}, \mathrm{Cl}$ and ALT. Sex did not influence ( $\mathrm{p}>$ $0.05)$ the values of the biochemical variables analyzed. Based on the results, it is concluded that the age groups exert a significant influence on the majority of blood biochemical variables of Dorper sheep from 15 to 121 days of age.
\end{abstract}

Key words: Blood biomarkers. Lamb. Sheep.

\section{Resumo}

Objetivou-se com o presente estudo avaliar as variações fisiológicas e influência das faixas etárias e sexo nas variáveis bioquímicas sanguíneas de 32 ovinos machos e fêmeas da raça Dorper dos 15 aos 121 dias de idade. Foram realizadas quatro coletas de sangue em cada animal, em intervalos mensais, totalizando 128 amostras. As variáveis bioquímicas determinadas em cada amostra foram proteína total (PT), albumina (ALB), globulinas (GLOB), relação albumina/globulina (A/G), glicose (GLI), triglicérides (TRI), colesterol total $\left(\mathrm{CHOL}_{\mathrm{t}}\right)$, lipoproteínas de alta densidade carreadoras de colesterol (HDL-C), lipoproteínas de baixa densidade carreadoras de colesterol (LDL-C), lipoproteínas

\footnotetext{
${ }^{1}$ Discente, Curso de Mestrado em Ciências Veterinárias, FAMEV, Universidade Federal de Uberlândia, UFU, Uberlândia, MG, Brasil. E-mail: berreka2005@hotmail.com

${ }^{2}$ Médicos Veterinários Autônomos, Uberlândia, MG, Brasil. E-mail: fmrocha-vet@hotmail.com; cassiusvet@hotmail.com

${ }^{3}$ Pesquisador Dr., Agência Goiânia de Defesa Agropecuária, AGRODEFESA, Goiânia, GO, Brasil. E-mail: pablo_noleto@ hotmail.com

${ }^{4}$ Prof. Dr., FAMAT, Universidade Federal de Uberlândia, UFU, Uberlândia, MG, Brasil. E-mail: ecg@ufu.br

5 Prof. Dr., ICBIM, UFU, Uberlândia, MG, Brasil. E-mail: galo@ufu.br

${ }^{6}$ Prof. Dr., FAMEV, UFU, Uberlândia, MG, Brasil. E-mail: antoniomundim@ufu.br

* Author for correspondence
} 
de muito baixa densidade carreadoras de colesterol (VLDL-C), ureia, creatinina (CREA), cálcio total $\left(\mathrm{Ca}_{\mathrm{t}}\right)$, cálcio ionizado $\left(\mathrm{Ca}_{\mathrm{i}}\right)$, fósforo $(\mathrm{P})$, relação cálcio/fósforo $(\mathrm{Ca} / \mathrm{P})$, magnésio $(\mathrm{Mg})$, sódio $(\mathrm{Na})$, potássio $(\mathrm{K})$, cloreto $(\mathrm{Cl})$, alanina aminotransferase (ALT), aspartato aminotransferase (AST), gama glutamiltransferase (GGT) e fosfatase alcalina (FAL). Os resultados foram obtidos em quatro momentos de acordo com a idade: M1 - ovinos de 15 a 30 dias, M2 - ovinos de 45 a 61 dias, M3 - ovinos de 74 a 90 dias e M4 - ovinos de 105 a 121 dias. Comparados os valores das variáveis bioquímicas entre as quatro faixas etárias estudadas observou-se diferença significativa $(\mathrm{p}<0,05)$ nas concentrações de todas as variáveis avaliadas com exceção de $\mathrm{Na}, \mathrm{Cl}$ e ALT. O sexo não influenciou $(\mathrm{p}>0,05)$ os valores das variáveis bioquímicas sanguíneas analisadas. Com base nos resultados conclui-se que as faixas etárias exercem influência significativa na maioria das variáveis bioquímicas sanguíneas de ovinos da raça Dorper dos 15 aos 121 dias de idade.

Palavras-chave: Biomarcadores sanguíneos. Cordeiros lactentes. Ovinos.

\section{Introduction}

Sheep breeding is common worldwide. A significant increase has been observed in sheep breeding in Brazil as a result of the numerous advantages associated with their breeding, such as the need for a smaller breeding area, lower food intake, easy management, and good production diversity, including quality meat, milk, and leather (PEREIRA et al., 2015).

Dorper sheep emerged in South Africa in 1930; they are rustic, prolific, highly adaptable to adverse temperatures, and have an excellent carcass finish (SOUSA; LEITE, 2000). Due to these characteristics, the breed was introduced in Brazil in 1998 (CARVALHO et al., 2001). With the intensification of production systems, sheep breeding necessitates the use of a variety of diagnostic methods owing to the higher incidence of metabolic diseases (PEREIRA et al., 2015).

Blood biochemistry is an essential diagnostic tool in the investigation of sheep diseases (BRAUN et al., 2010). Several factors have been described as possible causes of significant changes in the blood biochemistry of sheep (MEIRA JÚNIOR et al., 2009). The blood biochemical profile may be influenced by age, sex, nutrition, breed, species, and environmental conditions (LIMA et al., 2015), as animals with different physiological and behavioral characteristics have different nutritional, energy, and metabolic requirements, which are reflected in their biochemical profiles (MADUREIRA et al.,
2013). This subject inspired several researchers to establish reference intervals for sheep of different breeds, regions, and management systems.

Studies of the blood biochemistry of pure Dorper sheep in growth phase are rare in the literature. Available references include Madureira et al. (2013) and Souza et al.(2016); they determined the reference values for this breed and verified the influence of the factors of age and sex. According to Madureira et al. (2013), physiological variation is important for the interpretation of laboratory findings; in conjunction with the physical examination of the patient, it is possible to establish the diagnosis and prognosis of the primary diseases that affect sheep. On the basis of this information, the purpose of this study was to evaluate the physiological variations and influences of age groups and sex on the blood biochemistry of prepubescent Dorper lambs aged 15 to 121 days.

\section{Materials and Methods}

The present study was approved by the Ethics Committee on Animal Use of the Universidade Federal de Uberlândia (CEUA/UFU) according to opinion $055 / 09$. The study was conducted from February to July using 32 pure Dorper sheep (13 males and 19 females) aged 15 to 121 days, bred at Cabanha Ovinos do Sena, municipality of Uberlândia, MG. The facility is at latitude $18^{\circ} 54^{\prime} 41^{\prime \prime}$ South, longitude $48^{\circ} 15^{\prime} 44^{\prime \prime}$ 'West, and at an altitude of $843 \mathrm{~m}$. The region has a tropical altitude climate with a dry season. 
The sheep remained housed in collective pens from the age of 15 to 90 days, with controlled nursing at 9:00 a.m. and at 3:00 p.m., and received a corn, soybean, mineral salt, and hay based balanced diet in a trough. After the age of 90 days, already weaned, they were separated by sex, housed in pens with a maximum of 4 animals per pen, and received the same balanced diet with a higher percentage of hay; there was no food deprivation. During the experiment, the animals also received 3 doses of a vaccine against clostridiosis at monthly intervals from the age of 15 days.

Four blood samples were collected from the 32 animals from the age of 15 days. Samples were collected at monthly intervals in the afternoons at approximately 2:00 p.m., before the second milk feeding; 128 total samples were collected. Two blood samples were collected from each animal at each sampling time by venipuncture of the external jugular vein, one of $3 \mathrm{~mL}$ in a tube without anticoagulant to obtain serum, and another of $2 \mathrm{~mL}$ in a tube containing EDTA and sodium fluoride to obtain plasma and for determination of glycemia.

After collection, the samples were sent to the Veterinary Clinical Laboratory of UFU in isothermal boxes containing recyclable ice, where they were centrifuged at $720 \times g$ for 6 minutes. The serum and plasma samples obtained were transferred to microtubes of 1,5 mL (Eppendorf); the plasma glycemia was determined on the same day of collection, and the serum biochemical analyses were processed within a maximum of 24 hours after collection. The biochemical analyses were conducted in a Chemwell automatic analyzer, previously calibrated (Calibra $\mathrm{H}$ ) and gauged with control serum (Qualitrol 1) at $37{ }^{\circ} \mathrm{C}$ using Labtest Diagnóstica ${ }^{\circledR}$ kits.

The glucose concentrations (GLU) of the plasma samples were determined using the enzymatic method (God trinder). In the serum samples, the concentrations were determined for total protein (TP) (biuret method); albumin (ALB) (bromocresol green method); triglycerides (TG) and total cholesterol $\left({ }_{t} \mathrm{CHOL}\right)$ (Trinder enzymatic method); high density cholesterol-carrying lipoproteins (HDL-C) (Trinder enzymatic method after selective precipitation of the low density cholesterol-carrying lipoproteins (LDL-C) and very low density cholesterol-carrying lipoproteins (VLDL-C); urea (UV enzymatic kinetic method); creatinine (CRE) (modified Jaffe method); total calcium ${ }_{t} \mathrm{Ca}$ ) (cresolphthalein complexone method); phosphorus (P) (UV kinetic method); and magnesium (Mg) (Magon sulfonate method); as well as the activities of the gamma-glutamyl transferase (GGT) (modified Szasz method), alanine aminotransferase (ALT), aspartate aminotransferase (AST), and alkaline phosphatase (ALP) enzymes (UV kinetic method, International Federation of Clinical Chemistry). The serum concentrations of the sodium $(\mathrm{Na})$, potassium $(\mathrm{K})$, and chlorine $(\mathrm{Cl})$ electrolytes were determined by the ion-selective electrode method in the EasyLyte ${ }^{\circledR}$ Plus analyzer previously gauged with control serum (Control $\mathrm{Lab})$. The values of the globulins (GLB $=\mathrm{TP}-$ ALB); the albumin/globulin ratio $(\mathrm{A} / \mathrm{G})$; and the calcium/phosphorus ratio $(\mathrm{Ca} / \mathrm{P})$ were determined. Ionized calcium $\left({ }_{\mathrm{i}} \mathrm{Ca}\right)$ was calculated according to the equation provided by the kit manufacturer: $\mathrm{Ca}_{\mathrm{i}}$ $=6 \times \mathrm{Ca}-[\mathrm{ALB}+(0.19 \times \mathrm{TP}) / 3] / \mathrm{ALB}+(0.19$ $\times \mathrm{TP})+6$. The equation of Friedewald et al. (1972) was used for the calculation of serum concentrations of LDL-C and VLDL-C.

The results obtained were presented in four different moments (M) according to age. M1 lasted from 15 to 30 days of age and comprised the neonatal lamb phase. M2 lasted from 45 to 61 days and comprised the suckling lamb phase. M3 lasted from 74 to 90 days and comprised the late suckling lamb phase, and M4 lasted from 105 to 121 days and comprised the weaned lamb phase.

The Action tool (http://www.portalaction.com. $\mathrm{br} /$ ) was used for statistical analysis and the data were presented as medians and percentiles. The variables were subjected to the Shapiro-Wilk normality test, which revealed non-Gaussian distribution; thus, 
non-parametric analysis was used. The comparison of the values between the age groups and sexes was conducted using the Kruskal-Wallis test; a p-value $<0.05$ was considered significant.

\section{Results and Discussion}

The median and percentile values and the results of the statistical analysis of the biochemical variables determined in Dorper sheep aged 15 to 121 days are shown in Tables 1 and 2.

Table 1. The median (Md) and percentile (P25 - P75) values of blood proteins, metabolites, and lipoproteins in Dorper sheep $(\mathrm{n}=32)$ according to age. Sheep were bred in Uberlândia, Minas Gerais, Brazil.

\begin{tabular}{|c|c|c|c|c|c|c|}
\hline $\begin{array}{c}\text { Biochemical } \\
\text { variables }\end{array}$ & & $\begin{array}{c}\text { Moment } 1 \\
\text { (15 to } 30 \text { days) }\end{array}$ & $\begin{array}{c}\text { Moment } 2 \\
\text { (45 to } 61 \text { days) }\end{array}$ & $\begin{array}{c}\text { Moment } 3 \\
\text { ( } 74 \text { to } 90 \text { days) }\end{array}$ & $\begin{array}{c}\text { Moment } 4 \\
\text { (105 to } \\
121 \text { days) }\end{array}$ & $\begin{array}{c}\text { General } \\
(15 \text { to } \\
121 \text { days })\end{array}$ \\
\hline $\begin{array}{c}\mathrm{TP} \\
\left(\mathrm{g} \mathrm{dL}^{-1}\right)\end{array}$ & $\begin{array}{c}\text { Md } \\
\text { P25-P75 }\end{array}$ & $\begin{array}{c}6.00 \mathrm{a} \\
(5.80-6.30)\end{array}$ & $\begin{array}{c}5.85 \mathrm{ab} \\
(5.50-6.20)\end{array}$ & $\begin{array}{c}5.40 \mathrm{bc} \\
(5.30-5.90)\end{array}$ & $\begin{array}{c}5.00 \mathrm{c} \\
(4.50-5.50)\end{array}$ & $\begin{array}{c}5.60 \\
(5.30-6.00)\end{array}$ \\
\hline $\begin{array}{c}\mathrm{ALB} \\
\left(\mathrm{g} \mathrm{dL}^{-1}\right)\end{array}$ & $\begin{array}{c}\mathrm{Md} \\
\mathrm{P} 25-\mathrm{P} 75\end{array}$ & $\begin{array}{c}2.70 \mathrm{ab} \\
(2.60-2.80)\end{array}$ & $\begin{array}{c}3.00 \mathrm{a} \\
(2.42-3.20)\end{array}$ & $\begin{array}{c}2.40 \mathrm{c} \\
(2.30-2.50)\end{array}$ & $\begin{array}{c}2.50 \mathrm{bc} \\
(2.30-2.70)\end{array}$ & $\begin{array}{c}2.60 \\
(2.40-2.80)\end{array}$ \\
\hline $\begin{array}{c}\mathrm{GLB} \\
\left(\mathrm{g} \mathrm{dL}^{-1}\right)\end{array}$ & $\begin{array}{c}\mathrm{Md} \\
\mathrm{P} 25-\mathrm{P} 75\end{array}$ & $\begin{array}{c}3.30 \mathrm{a} \\
(3.10-3.60)\end{array}$ & $\begin{array}{c}2.80 \mathrm{~b} \\
(2.50-3.20)\end{array}$ & $\begin{array}{c}3.10 \mathrm{ab} \\
(2.82-3.50)\end{array}$ & $\begin{array}{c}2.60 \mathrm{~b} \\
(2.12-2.90)\end{array}$ & $\begin{array}{c}3.00 \\
(2.60-3.30)\end{array}$ \\
\hline $\begin{array}{l}\mathrm{A} / \mathrm{G} \\
\text { ratio }\end{array}$ & $\begin{array}{c}\text { Md } \\
\text { P25-P75 }\end{array}$ & $\begin{array}{c}0.82 \mathrm{~b} \\
(0.74-0.89)\end{array}$ & $\begin{array}{c}1.06 \mathrm{a} \\
(0.78-1.21)\end{array}$ & $\begin{array}{c}0.71 b \\
(0.69-0.85)\end{array}$ & $\begin{array}{c}0.97 \mathrm{a} \\
(0.91-1.09)\end{array}$ & $\begin{array}{c}0.90 \\
(0.72-1.04)\end{array}$ \\
\hline $\begin{array}{c}\mathrm{GLU} \\
\left(\mathrm{mg} \mathrm{dL}^{-1}\right)\end{array}$ & $\begin{array}{c}\text { Md } \\
\text { P25-P75 }\end{array}$ & $\begin{array}{c}85.40 \mathrm{a} \\
(80.85-98.75)\end{array}$ & $\begin{array}{c}78.60 \mathrm{a} \\
(73.85-82.00)\end{array}$ & $\begin{array}{c}65.60 \mathrm{~b} \\
(60.22-69.40)\end{array}$ & $\begin{array}{c}52.10 \mathrm{~b} \\
(48.50-59.05)\end{array}$ & $\begin{array}{c}69.60 \\
(58.80-81.40)\end{array}$ \\
\hline $\begin{array}{c}\mathrm{TG} \\
(\mathrm{mg} \mathrm{dL}-1)\end{array}$ & $\begin{array}{c}\text { Md } \\
\text { P25-P75 }\end{array}$ & $\begin{array}{c}120.80 \mathrm{a} \\
(88.95-175.30)\end{array}$ & $\begin{array}{c}26.90 \mathrm{~b} \\
(21.57-36.02)\end{array}$ & $\begin{array}{c}26.35 b \\
(19.30-35.82)\end{array}$ & $\begin{array}{c}31.05 b \\
(18.42-51.10)\end{array}$ & $\begin{array}{c}32.60 \\
(21.80-59.00)\end{array}$ \\
\hline $\begin{array}{c}{ }_{\mathrm{t}}^{\mathrm{CHOL}} \\
\left(\mathrm{mg} \mathrm{dL} \mathrm{dH}^{-1}\right)\end{array}$ & $\begin{array}{c}\text { Md } \\
\text { P25-P75 }\end{array}$ & $\begin{array}{c}132.80 \mathrm{a} \\
(117.85-161.05)\end{array}$ & $\begin{array}{c}52.10 \mathrm{~b} \\
(45.52-59.00)\end{array}$ & $\begin{array}{c}40.30 \mathrm{c} \\
(35.50-48.00)\end{array}$ & $\begin{array}{c}57.30 \mathrm{~b} \\
(46.82-70.55)\end{array}$ & $\begin{array}{c}55.60 \\
(43.00-101.80)\end{array}$ \\
\hline $\begin{array}{l}\text { HDL-C } \\
\left(\mathrm{mg} \mathrm{dL}^{-1}\right)\end{array}$ & $\begin{array}{c}\mathrm{Md} \\
\mathrm{P} 25-\mathrm{P} 75\end{array}$ & $\begin{array}{c}60.40 \mathrm{a} \\
(46.50-71.80)\end{array}$ & $\begin{array}{c}16.55 b \\
(14.87-19.10)\end{array}$ & $\begin{array}{c}15.20 \mathrm{~b} \\
(13.60-17.60)\end{array}$ & $\begin{array}{c}17.55 b \\
(15.55-20.07)\end{array}$ & $\begin{array}{c}17.60 \\
(15.20-23.20)\end{array}$ \\
\hline $\begin{array}{l}\text { LDL-C } \\
(\mathrm{mg} \mathrm{dL-1)}\end{array}$ & $\begin{array}{c}\text { Md } \\
\text { P25-P75 }\end{array}$ & $\begin{array}{c}41.80 \mathrm{a} \\
(31.75-56.35)\end{array}$ & $\begin{array}{c}28.55 b \\
(23.10-34.90)\end{array}$ & $\begin{array}{c}21.35 \mathrm{c} \\
(16.20-25.25)\end{array}$ & $\begin{array}{c}30.15 \mathrm{ab} \\
(19.50-48.67)\end{array}$ & $\begin{array}{c}29.30 \\
(21.30-41.70)\end{array}$ \\
\hline $\begin{array}{l}\text { VLDL-C } \\
\left(\mathrm{mg} \mathrm{dL}^{-1}\right)\end{array}$ & $\begin{array}{c}\text { Md } \\
\text { P25-P75 }\end{array}$ & $\begin{array}{c}24.10 \mathrm{a} \\
(17.80-35.05)\end{array}$ & $\begin{array}{c}5.40 \mathrm{~b} \\
(4.30-7.20)\end{array}$ & $\begin{array}{c}5.25 \mathrm{~b} \\
(3.90-7.17)\end{array}$ & $\begin{array}{c}6.25 \mathrm{~b} \\
(3.65-10.27)\end{array}$ & $\begin{array}{c}6.50 \\
(4.40-12.40)\end{array}$ \\
\hline $\begin{array}{c}\text { UREA } \\
\left(\mathrm{mg} \mathrm{dL}^{-1}\right)\end{array}$ & $\begin{array}{c}\mathrm{Md} \\
\mathrm{P} 25-\mathrm{P} 75\end{array}$ & $\begin{array}{c}40.50 \mathrm{a} \\
(36.05-56.05)\end{array}$ & $\begin{array}{c}59.10 \mathrm{a} \\
(41.62-76.85)\end{array}$ & $\begin{array}{c}32.30 \mathrm{~b} \\
(23.32-39.97)\end{array}$ & $\begin{array}{c}28.75 b \\
(19.40-36.42)\end{array}$ & $\begin{array}{c}38.80 \\
(28.30-52.70)\end{array}$ \\
\hline $\begin{array}{c}\mathrm{CRE} \\
\left(\mathrm{mg} \mathrm{dL}^{-1}\right)\end{array}$ & $\begin{array}{c}\text { Md } \\
\text { P25-P75 }\end{array}$ & $\begin{array}{c}1.10 \mathrm{a} \\
(0.90-1.20)\end{array}$ & $\begin{array}{c}1.10 \mathrm{a} \\
(1.00-1.30)\end{array}$ & $\begin{array}{c}0.90 \mathrm{~b} \\
(0.80-1.00)\end{array}$ & $\begin{array}{c}0.90 \mathrm{~b} \\
(0.86-1.00)\end{array}$ & $\begin{array}{c}1.00 \\
(0.90-1.10)\end{array}$ \\
\hline
\end{tabular}

$(\mathrm{a}, \mathrm{b}, \mathrm{c})$ Median values followed by different lower-case letters in the same line indicate significant differences between age groups $(\mathrm{p}<0.05)$.

Protein and metabolite values of the sheep in the present study were compared with those available in the literature; the values of TP, ALB, and GLB remained within the intervals reported in previous studies (ROUBIES et al., 2006; LEPHERD et al., 2009; MEIRA JÚNIOR et al., 2009; MADUREIRA et al., 2013; SOUZA et al., 2014; CARLOS et al., 2015; STEVANOVIC et al., 2015). The GLU, TG, and $\mathrm{CHOL}$ values remained within the intervals obtained by Carlos et al. (2015); the HDL-C, LDL-C, and VLDL-C values were close to the values of Sitmo (2014), and the CRE and urea values were within the intervals cited by other researchers (MADUREIRA et al., 2013; SITMO, 2014; CARLOS et al., 2015; LIMA et al., 2015). 
Comparing the values of the biochemical variables among the four age groups studied (Table $1)$, significant differences $(\mathrm{p}<0.05)$ were observed in the protein and metabolite concentrations evaluated. The TP and GLB concentrations were higher $(p<0.05)$ in M1, while those of ALB were higher $(\mathrm{p}<0.05)$ in M2. The higher values of TP and GLB in lambs in M1 may be explained by the intake of immunoglobulins through colostrum, which contributed to the high levels of total proteins and globulins in the blood serum (RAMOS et al., 1994).

Table 2. The median (Md) and percentile (P25 - P75) values of serum minerals, electrolytes, and enzymes in Dorper sheep $(n=32)$ according to age group. Sheep were bred in Uberlândia, Minas Gerais, Brazil.

\begin{tabular}{|c|c|c|c|c|c|c|}
\hline $\begin{array}{c}\text { Biochemical } \\
\text { variables }\end{array}$ & & $\begin{array}{c}\text { Moment } 1 \\
\text { (15 to } 30 \text { days) }\end{array}$ & $\begin{array}{c}\text { Moment } 2 \\
\text { (45 to } 61 \text { days) }\end{array}$ & $\begin{array}{c}\text { Moment } 3 \\
\text { (74 to } 90 \text { days) }\end{array}$ & $\begin{array}{c}\text { Moment } 4 \\
\text { (105 to } 121 \text { days) }\end{array}$ & $\begin{array}{c}\text { General } \\
\text { (15 to } 121 \text { days) }\end{array}$ \\
\hline $\begin{array}{c}\mathrm{Ca} \\
\left(\mathrm{mg} \mathrm{dL}^{-1}\right)\end{array}$ & $\begin{array}{c}\text { Md } \\
\text { P25-P75 }\end{array}$ & $\begin{array}{c}12.60 \mathrm{a} \\
(11.90-13.00)\end{array}$ & $\begin{array}{c}11.50 \mathrm{~b} \\
(10.65-12.12)\end{array}$ & $\begin{array}{c}10.05 \mathrm{c} \\
(9.30-10.52)\end{array}$ & $\begin{array}{c}10.00 \mathrm{c} \\
(9.47-10.32)\end{array}$ & $\begin{array}{c}10.80 \\
(9.90-12.10)\end{array}$ \\
\hline $\begin{array}{c}\mathrm{Ca} \\
\left(\mathrm{mg} \mathrm{dL}^{-1}\right)\end{array}$ & $\begin{array}{c}\text { Md } \\
\text { P25-P75 }\end{array}$ & $\begin{array}{c}7.48 \mathrm{a} \\
(7.15-7.80)\end{array}$ & $\begin{array}{c}6.23 b \\
(5.96-6.68)\end{array}$ & $\begin{array}{c}5.68 \mathrm{c} \\
(5.52-6.06)\end{array}$ & $\begin{array}{c}5.56 \mathrm{c} \\
(4.84-6.05)\end{array}$ & $\begin{array}{c}6.11 \\
(5.59-7.00)\end{array}$ \\
\hline $\begin{array}{c}\mathrm{P} \\
\left(\mathrm{mg} \mathrm{dL}^{-1}\right)\end{array}$ & $\begin{array}{c}\text { Md } \\
\text { P25-P75 }\end{array}$ & $\begin{array}{c}9.00 \mathrm{a} \\
(8.70-9.50)\end{array}$ & $\begin{array}{c}9.25 \mathrm{a} \\
(8.78-9.95)\end{array}$ & $\begin{array}{c}8.80 \mathrm{a} \\
(8.27-9.20)\end{array}$ & $\begin{array}{c}7.35 b \\
(6.42-7.80)\end{array}$ & $\begin{array}{c}8.80 \\
(7.80-9.30)\end{array}$ \\
\hline $\begin{array}{l}\mathrm{Ca} / \mathrm{P} \\
\text { ratio }\end{array}$ & $\begin{array}{c}\text { Md } \\
\text { P25-P75 }\end{array}$ & $\begin{array}{c}1.41 \mathrm{a} \\
(1.29-1.43)\end{array}$ & $\begin{array}{c}1.24 b \\
(1.18-1.31)\end{array}$ & $\begin{array}{c}1.15 \mathrm{c} \\
(1.09-1.18)\end{array}$ & $\begin{array}{c}1.27 b \\
(1.20-1.46)\end{array}$ & $\begin{array}{c}1.24 \\
(1.16-1.38)\end{array}$ \\
\hline $\begin{array}{c}\mathrm{Mg} \\
\left(\mathrm{mg} \mathrm{dL}^{-1}\right)\end{array}$ & $\begin{array}{c}\text { Md } \\
\text { P25-P75 }\end{array}$ & $\begin{array}{c}2.40 \mathrm{~b} \\
(2.20-2.75)\end{array}$ & $\begin{array}{c}3.20 \mathrm{a} \\
(2.90-3.57)\end{array}$ & $\begin{array}{c}3.20 \mathrm{a} \\
(2.90-3.62)\end{array}$ & $\begin{array}{c}3.05 \mathrm{a} \\
(2.80-3.40)\end{array}$ & $\begin{array}{c}3.00 \\
(2.60-3.40)\end{array}$ \\
\hline $\begin{array}{c}\mathrm{Na} \\
\left(\mathrm{mEq} \mathrm{L}^{-1}\right)\end{array}$ & $\begin{array}{c}\text { Md } \\
\text { P25-P75 }\end{array}$ & $\begin{array}{c}148.60 \mathrm{a} \\
(146.55-151.40)\end{array}$ & $\begin{array}{c}143.40 \mathrm{a} \\
(139.60-148.85)\end{array}$ & $\begin{array}{c}148.00 \mathrm{a} \\
(147.15-151.47)\end{array}$ & $\begin{array}{c}147.00 \mathrm{a} \\
(144.10-153.17)\end{array}$ & $\begin{array}{c}147.80 \\
(144.40-151.10)\end{array}$ \\
\hline$\frac{\mathrm{K}}{\left(\mathrm{mEq} \mathrm{L} \mathrm{L}^{-1}\right)}$ & $\begin{array}{c}\text { Md } \\
\text { P25-P75 }\end{array}$ & $\begin{array}{c}4.99 \mathrm{~b} \\
(4.77-5.17)\end{array}$ & $\begin{array}{c}4.98 \mathrm{~b} \\
(4.56-5.15)\end{array}$ & $\begin{array}{c}5.67 \mathrm{a} \\
(5.17-6.33)\end{array}$ & $\begin{array}{c}5.63 a \\
(5.10-6.42)\end{array}$ & $\begin{array}{c}5.17 \\
(4.81-5.67)\end{array}$ \\
\hline $\begin{array}{c}\mathrm{Cl} \\
\left(\mathrm{mEq} \mathrm{L}^{-1}\right)\end{array}$ & $\begin{array}{c}\text { Md } \\
\text { P25-P75 }\end{array}$ & $\begin{array}{c}110.60 \mathrm{a} \\
(105.40-113-85)\end{array}$ & $\begin{array}{c}108.40 \mathrm{a} \\
(105.80-111.05)\end{array}$ & $\begin{array}{c}108.55 a \\
(106.75-112-77)\end{array}$ & $\begin{array}{c}110.00 \mathrm{a} \\
(106.42-111.65)\end{array}$ & $\begin{array}{c}109.40 \\
(106.20-112.30)\end{array}$ \\
\hline $\begin{array}{c}\text { ALT } \\
\left(\mathrm{U} \mathrm{L}^{-1}\right)\end{array}$ & $\begin{array}{c}\text { Md } \\
\text { P25-P75 }\end{array}$ & $\begin{array}{c}15.00 \mathrm{a} \\
(12.00-17.00)\end{array}$ & $\begin{array}{c}16.50 \mathrm{a} \\
(13.00-18.25)\end{array}$ & $\begin{array}{c}14.50 \mathrm{a} \\
12.75-19.25)\end{array}$ & $\begin{array}{c}16.00 \mathrm{a} \\
(14.00-19.50)\end{array}$ & $\begin{array}{c}16.00 \\
(13.00-19.00)\end{array}$ \\
\hline $\begin{array}{l}\mathrm{AST} \\
\left(\mathrm{U} \mathrm{L}^{-1}\right)\end{array}$ & $\begin{array}{c}\text { Md } \\
\text { P25-P75 }\end{array}$ & $\begin{array}{c}49.00 \mathrm{~b} \\
(44.50-57.00)\end{array}$ & $\begin{array}{c}134.50 \mathrm{a} \\
(123.37-145-75)\end{array}$ & $\begin{array}{c}118.00 \mathrm{a} \\
(105.50-131.25)\end{array}$ & $\begin{array}{c}136.50 \mathrm{a} \\
(129.00-148.75)\end{array}$ & $\begin{array}{c}125.00 \\
(91.00-138.00)\end{array}$ \\
\hline $\begin{array}{l}\text { GGT } \\
\left(\mathrm{U} \mathrm{L}^{-1}\right)\end{array}$ & $\begin{array}{c}\text { Md } \\
\text { P25-P75 }\end{array}$ & $\begin{array}{c}69.30 \mathrm{a} \\
(52.60-87.40)\end{array}$ & $\begin{array}{c}45.70 b \\
(36.82-52.37)\end{array}$ & $\begin{array}{c}35.00 \mathrm{c} \\
(32.00-39.82)\end{array}$ & $\begin{array}{c}35.95 \mathrm{c} \\
(32.35-42.40)\end{array}$ & $\begin{array}{c}42.50 \\
(34.90-57.50)\end{array}$ \\
\hline $\begin{array}{c}\text { ALP } \\
\left(\mathrm{U} \mathrm{L}^{-1}\right)\end{array}$ & $\begin{array}{c}\mathrm{Md} \\
\mathrm{P} 25-\mathrm{P} 75\end{array}$ & $\begin{array}{c}503.60 \mathrm{a} \\
(443.80-614.00)\end{array}$ & $\begin{array}{c}583.55 \mathrm{a} \\
(522.27-672.27)\end{array}$ & $\begin{array}{c}134.10 b \\
(118.37-165.62)\end{array}$ & $\begin{array}{c}161.70 b \\
(134.25-189.52)\end{array}$ & $\begin{array}{c}275.40 \\
(148.90-562.50)\end{array}$ \\
\hline
\end{tabular}

$(\mathrm{a}, \mathrm{b}, \mathrm{c})$ Median values followed by different lower-case letters in the same line indicate significant differences between age groups $(\mathrm{p}<0.05)$.

Delfino et al. (2014) studied calves and observed significantly higher values of TP and GLB in younger animals; the difference was attributed to the absorption of immunoglobulins due to the ingestion of colostrum. The increased serum concentrations of TP and GLB may also be attributed to the response to the vaccine challenge of the animals in this study. The concentration of TP is low at birth and rapidly increases after ingestion of colostrum (LOSTE et al., 2008; MEIRA JÚNIOR et al., 2009). Souza et al. (2014) observed an increase in TP concentration in lambs in response to the significant increase of GLB contents and to the slight decrease in ALB concentration after ingestion of colostrum.

The higher values of ALB in younger animals are consistent with the findings of Piccione et al. (2013), who observed the increase in albumin from the third week of life, after which the liver 
is responsible for the synthesis of albumin. They also corroborated the findings of Silva et al. (2010), who reported variations in TP, ALB, and GLB with age and attributed these changes to the ingestion of colostrum after birth, ingestion of nitrogen compounds, and the active endogenous production of immunoglobulins due to environmental challenges and vaccine responses. According to Meira Júnior et al. (2009), higher serum values of albumin are observed in younger animals in growth phases with higher metabolic demands, such as the animals in M2 of the present study. The higher value of the $A / G$ ratio $(p<0.05)$ in animals in $M 2$ and M4 resulted from the lower concentrations of serum globulins in these age groups.

The higher concentrations of GLU $(p<0.05)$ in younger animals (M1 and M2) are consistent with the findings of Souza et al. (2014), who attributed this increase to breastfeeding, as the consumption of nutrients through breastfeeding directly interferes with the absorption and metabolism of carbohydrates. According to Braun et al. (2010), increased GLU concentrations in new lambs may also be due to stress. According to Gregory et al. (2009), and the observations in the present study, the higher concentrations of GLU in younger animals show that milk is an important source of energy for newborns, and the quantity of milk in the diet reduces with age due to modification of food and energy metabolism of non-suckling animals.

The higher concentrations of $\mathrm{TG},{ }_{\mathrm{t}} \mathrm{CHOL}$, HDL-C, LDL-C, and VLDL-C $(p<0.05)$ in M1 lambs are due to the milk-based diet. As stated by Ramos et al. (1994), the accumulation of fat is higher in younger animals; as the animal matures, there is a progressive reduction of serum cholesterol due to the change in diet. The primary source of energy in milk is in the form of lipids; consequently, lipid levels increase, especially CHOL (GREGORY et al., 2009). Souza et al. (2014) observed significant increases in TG and $\mathrm{CHOL}$ concentrations in lambs after ingestion of colostrum. Similarly, Bennis et al. (1992) also observed significant increases in
$\mathrm{TG}$ and $\mathrm{CHOL}$ concentrations in newborn kids after colostrum ingestion. As the lambs in this study aged, there were significant reductions in the concentrations of ${ }_{t} \mathrm{CHOL}$ and HDL-C, which concurred with the results of Eshratkhah et al. (2010).

The higher concentrations of urea $(p<0.05)$ in the younger sheep of the present study (M1 and M2) are attributed to the higher consumption and breakdown of proteins in this phase of life, as lambs have an intense protein metabolism to meet growth requirements. Urea is a metabolite involved in the excretion of nitrogen; thus, it may change according to the protein content of the diet (CONTI et al., 2015).

The observation of higher CRE concentrations $(\mathrm{p}<0.05)$ in M1 and M2 contradicts Lima et al. (2015), who observed an age-related creatinine increase in sheep due to the higher muscle mass. The higher CRE values in sheep aged up to 61 days in this study are attributed to the higher demand for phosphocreatine for muscle mass gain; creatinine is formed by the breakdown of phosphocreatine for the release of energy in skeletal muscle (CARLOS et al., 2015).

Comparing the values of minerals of the lambs of the present study with those in the literature, it was observed that the serum concentrations of $\mathrm{Ca}$ and $\mathrm{P}$ remained within the values cited by other researchers (ROUBIES et al., 2006; LEPHERD et al., 2009; STEVANOVIC etal., 2015), and the values of $\mathrm{Mg}$ were compatible with the values reported by Roubies et al. (2006) and Lepherd et al. (2009). The electrolytes $\mathrm{Na}, \mathrm{K}$, and $\mathrm{Cl}$ presented values similar to those observed in previous studies (GARDNER, 1973; LEPHERD et al., 2009; SITMO, 2014).

Comparing the values of minerals and electrolytes among the four age groups studied (Table 2$)$, the effect of age $(\mathrm{p}<0.05)$ was observed in all elements evaluated except $\mathrm{Na}$ and $\mathrm{Cl}$. According to Stevanovic et al. (2015), nutrition, quality of the pasture, and soil have significant 
effects on the serum concentrations of minerals. The higher values of $\mathrm{Ca},{ }_{\mathrm{i}} \mathrm{Ca}$, and the $\mathrm{Ca} / \mathrm{P}$ ratio $(\mathrm{p}$ $<0.05)$ in M1 lambs, and that of $\mathrm{P}$ in M1, M2, and M3 lambs, are because they are suckling animals and are in a growth phase with intense osteoblast activity (KANEKO et al., 2008).

According to Gomide et al. (2004), the higher concentrations of $\mathrm{Ca}$ and $\mathrm{P}$ in young animals are because growing animals have more efficient absorption of minerals due to the high rate of bone development, higher renal reabsorption, and bone mobilization.

According to Lepherd et al. (2009), growing animals present higher serum concentrations of phosphorus. The concentration of $\mathrm{P}$ in the sheep of the present study was above the reference values cited by Kaneko et al. (2008); it may be due to the young age of the sheep, as young animals absorb minerals more efficiently in the gastrointestinal tract due to the action of growth hormone and bone development (VICENTE et al., 2014; SOUZA et al., 2016). The variations observed for the $\mathrm{Ca} / \mathrm{P}$ ratio among the age groups studied were a result of the changes in the concentrations of $\mathrm{Ca}$ and $\mathrm{P}$ during the growth phase.

The lower concentration of $\mathrm{Mg}(\mathrm{p}<0.05)$ in younger animals (M1) is attributed to diet; during the M1, the diet mostly included milk, which is poor in Mg (TOKARNIA et al., 2010). As stated by Souza et al. (2016), sheep primarily fed on fodder have $\mathrm{Mg}$ concentrations higher than younger sheep whose diets consist almost exclusively of breast milk.

The higher concentration of $\mathrm{K}(\mathrm{p}<0.05)$ in sheep in M3 and M4, aged more than 74 days, is attributed to the higher amount of $\mathrm{K}$ in the diet, as these sheep ate more concentrate.

Regarding enzymes, the values of ALT remained within the intervals cited by Ramos et al. (1994) and Sitmo (2014), and the values of AST were compatible with those cited in previous studies (RAMOS et al.,
1994; KANEKO et al., 2008; LEPHERD et al., 2009; MEIRA JÚNIOR et al., 2009; MADUREIRA et al., 2013; SITMO, 2014; SOUZA et al., 2014; LIMA et al., 2015; STEVANOVIC et al., 2015). The values of GGT were also similar to those in previous studies (ROUBIES et al., 2006; KANEKO et al., 2008; LEPHERD et al., 2009; MEIRA JÚNIOR et al., 2009; STEVANOVIC et al., 2015); and the values of ALP were similar to those of Kaneko et al. (2008), Lepherd et al. (2009), Madureira et al. (2013), and Sitmo (2014).

When enzyme values among the four moments were compared, a significant difference $(p<0.05)$ was observed in AST, GGT, and ALP. The higher values of AST $(p<0.05)$ in M2, M3, and M4 were attributed to greater muscle mass and metabolic activity. These results are consistent with those of Meira Júnior et al. (2009), who observed the gradual increase of this enzyme with age.

The higher concentrations of GGT $(p<0.05)$ in M1 and the gradual reduction after 45 days are due to the high quantity of the enzyme ingested in the colostrum. This finding corroborates with those of Ramos et al. (1994), who observed higher serum activity of GGT in young sheep, which decreased with age, and with those of Delfino et al. (2014), who observed higher values of GGT in newborn calves and attributed them to higher absorption through ingested colostrum, which has high concentrations of the enzyme.

The higher activity of ALP $(p<0.05)$ in sheep in M1 and M2, with reduction from 74 days old, corroborates the findings of Madureira et al. (2013), who detected higher values of this enzyme in younger animals. As stated by Kaneko et al. (2008), this is due to the high quantity of bone isoenzymes released into the bloodstream in animals in the growth phase. González and Silva (2003) stated that the serum concentration of ALP is two to three times higher in young animals, which, according to Thrall et al. (2007), is due to intense osteoblast activity during the growth period. 
The sex of the animal did not influence the biochemical variables of the sheep in this study ( $p$ $>0.05$ ), corroborating the findings of Souza et al. (2016) and Eshratkhah et al. (2010), and differing from those of other researchers (MEIRA JÚNIOR et al., 2009; TELEB et al., 2009; MADUREIRA et al., 2013; SITMO, 2014; CARLOS et al., 2015; LIMA et al., 2015). All animals in this study were prepubescent.

\section{Conclusions}

On the basis of the results, it is concluded that age exerts a significant influence on the values of most biochemical variables of Dorper sheep aged 15 to 121 days, and that there is no difference between males and females.

\section{References}

BENNIS, A.; LAFARGE, F.; BÉZILLE, P.; VALDIGUIÉ, P.; RICO, A. G.; BRAUN, J. P. Effects of age of newborn and delivery by female goats on plasma lipids and lipoproteins. Small Ruminant Research, Amsterdam, v. 9, n. 3, p. 243-253, dez. 1992.

BRAUN, J. P.; TRUMEL, C.; BÉZILLE, P. Clinical biochemistry in sheep: a selected review. Small Ruminant Research, Amsterdam, v. 92, n. 1, p. 10-18, ago. 2010.

CARLOS, M. M. L.; LEITE, J. H. G. M.; CHAVES, D. F.; VALE, A. M.; FAÇANHA, D. A. E.; MELO, M. M.; SOTO-BLANCO, B. Blood parameters in the Morada Nova sheep: influence of age, sex, and body condition score. The Journal of Animal and Plant Sciences, Champaign, v. 25, n. 4, p. 950-955, out. 2015.

CARVALHO, E. B.; OLIVEIRA, M. A. G.; DOMINGUES, P. F. Base para criação de ovinos no Estado de São Paulo. São Manoel: ASPACO, 2001.93 p.

CONTI, R. M. C.; ZANETTI, M. A.; NETTO, A. S.; RODRIGUES, P. H. M.; PACHECO, J. C. G.; GARRINE, C. M. L. P.; YOSHIKAWA, C. Y. C. Efeitos de fontes orgânicas de cobre e enxofre sobre os parâmetros bioquímicos no soro de ovinos. Pesquisa Veterinária Brasileira, Rio de Janeiro, v. 35, n. 11, p. 875-881, out. 2015.

DELFINO, J. L.; BARBOSA, V. M.; GONDIM, C. C.; OLIVEIRA, P. M.; NASCIUTTI, N. R.; OLIVEIRA, R. S. B. R.; TSURUTA, S. A.; MUNDIM, A. V.; SAUT, J.
P. E. Perfil bioquímico sérico de bezerros senepol nos primeiros 120 dias de idade. Semina: Ciências Agrárias, Londrina, v. 35, n. 3, p. 1341-1350, maio/jun. 2014.

ESHRATKHAH, B.; SADAGHIAN, M.; ESHRATKHAH, S.; POURRABBI, S.; NAJAFIAN, K. Relationship between the blood thyroid hormones and lipid profile in Moghani sheep; influence of age and sex. Comparative Clinical Pathology, London, v. 19, n. 1, p. 15-20, fev. 2010.

FRIEDEWALD, W. T.; LEVY, R. I.; FREDRICKSON, D. S. Estimation of the concentration of low density lipoprotein cholesterol in plasma, without use of the preparative ultracentrifuge. Clinical Chemistry, Baltimore, v. 18, n. 1, p. 499-502, jun. 1972.

GARDNER, D. E. Values for certain blood and urine constituents of normal young lambs. New Zealand Veterinary Journal, Wellington, v. 21, n. 4, p. 70-73, abr. 1973.

GOMIDE, C. A.; ZANETTI, M. A.; PENTEADO, M. V. C.; CARRER, C. R. O.; DEL CLARO, G. R.; NETTO, A. S. Influência da diferença cátion aniônica da dieta sobre o balanço de cálcio, fósforo e magnésio em ovinos. Arquivo Brasileiro de Medicina Veterinária e Zootecnia, Belo Horizonte, v. 56, n. 3, p. 363-369, jan. 2004.

GONZÁlEZ, F. H. D.; SILVA, S. C. Introdução à bioquímica clínica veterinária. Porto Alegre: Gráfica URFGS, 2003. 198 p.

GREGORY, L.; BARDESE, C. B.; BIRGEL JÚNIOR, E. H.; MEIRA JÚNIOR, E. B. S.; PIVA, F. M.; HASEGAWA, M. Y. Lipidograma e glicemia de caprinos da raça Saanen, durante os primeiros dias de vida. ARS Veterinária, Jaboticabal, v. 25, n. 3, p. 109-115, jan. 2009.

KANEKO, J. J.; HARVEY, J. W.; BRUSS, M. L. Clinical biochemistry of domestic animals. $6^{\text {th }}$ ed. San Diego: Academic Press, 2008. 916 p.

LEPHERD, M. L.; CANFIELD, P. J.; HUNT, G. B.; BOSWARD, K. L. Haematological, biochemical and selected acute phase protein reference intervals for weaned female Merino lambs. Australian Veterinary Journal, Brunswick, v. 87, n. 1-2, p. 5-11, jan./fev. 2009.

LIMA, M. B.; MONTEIRO, M. V. B.; JORGE, E. M.; CAMPELLO, C. C.; RODRIGUES, L. F. S.; VIANA, R. B.; MONTEIRO, F. O. B.; COSTA, C. T. C. Intervalos de referência sanguíneos e a influência da idade e sexo sobre parâmetros hematológicos e bioquímicos de ovinos da raça Santa Inês criados na Amazônia Oriental. Acta Amazônica, Manaus, v. 45, n. 3, p. 317-322, set. 2015.

LOSTE, A.; RAMOS, J. J.; FERNANDEZ, A.; FERRE, L. M.; LACASTA, D.; VERDE, M. T.; MARCA, M. C.; ORTIN, A. Effect of colostrum treated by heat on 
immunological parameters in newborn lambs. Livestock Production Science, Amsterdam, v. 117, n. 2, p. 176-183, set. 2008 .

MADUREIRA, K. M.; GOMES, V.; BARCELOS, B.; ZANI, B. H.; SHECAIRA, C. L.; BACCILI, C. C.; BENESI, F. J. Parâmetros hematológicos e bioquímicos de ovinos da raça Dorper. Semina: Ciências Agrárias, Londrina, v. 34, n. 2, p. 811-816, mar./abr. 2013.

MEIRA JÚNIOR, E. B. S.; RIZZO, H.; BENESI, F. J.; GREGORY, L. Influência dos fatores sexuais e etários sobre a proteína total, fração albumina e atividade sérica de aspartato aminotransferase e gama glutamiltransferase de ovinos da raça Santa Inês. Brazilian Journal of Veterinary Research and Animal Science, São Paulo, v. 46, n. 6, p. 448-454, set. 2009.

PEREIRA, F. B.; BEZERRA, L. R.; MARQUES, C. A. T.; ARAÚJO, M. J.; TORREÃO, J. N. C.; MACHADO, L. P. Perfil hematológico de ovelhas Santa Inês suplementadas a pasto no terço final de gestação e no pós-parto. Ciência Animal Brasileira, Goiânia, v. 16, n. 3, p. 350-357, jul./ set. 2015.

PICCIONE, G.; ARFUSO, F.; FAGGIO, C.; CASELLA, S.; ZUMBO, A.; PANZERA, M. Serum proteins profile in Comisana lambs during the first month of life. Archiv Tierzucht, Dummerstorf, v. 56, n. 74, p. 742-750, jun. 2013.

RAMOS, J. J.; VERDE, M. T.; MARCA, M. C.; FERNÁNDEZ, A. Clinical chemical values and variations in Rasa Aragonesa ewes and lambs. Small Ruminant Research, Amsterdam, v. 13, n. 1, p. 133-139, mar. 1994.

ROUBIES, N.; PANOUSIS, N.; FYTIANOU, A.; KATSOULOS, P. D.; GIADINIS, N.; KARATZIAS, H. Effects of age and reproductive stage on certain serum biochemical parameters of chios sheep under greek rearing conditions. Journal of Veterinary Medicine, Berlin, v. 53, n. 6, p. 277-281, ago. 2006.

SILVA, D. F. M.; COSTA, J. N.; ARAÚJO, A. L.; COSTA NETO, A. O.; ALMEIDA, M. A. O.; CARVALHO, V. S. Proteinograma sérico de cordeiros mestiços (Santa Inês x Dorper) do nascimento até o desmame: efeito do desenvolvimento etário e do monitoramento da ingestão do colostro. Ciência Animal Brasileira, Goiânia, v. 11, n. 4, p. 794-805, out./dez. 2010.
SITMO, M. S. Effect of gender on some plasma biochemical parameters of sheep from Southern Al Jabal Al Akhdar in Libya. Journal of American Science, New York, v. 10, n. 8, p. 74-77, out. 2014.

SOUSA, W. H.; LEITE, P. R. M. Ovinos de corte: a raça Dorper. João Pessoa: EMEPA, 2000. 75 p.

SOUZA, B. C.; SENA, L. S.; LOUREIRO, D.; RAYNAL, J. T.; SOUSA, T. J.; BASTOS, B. L.; MEYER, R.; PORTELA, R. W. Determinação de valores de referência séricos para os eletrólitos magnésio, cloretos, cálcio e fósforo em ovinos das raças Dorper e Santa Inês. Pesquisa Veterinária Brasileira, Rio de Janeiro, v. 36, n. 3, p. 167-173, mar. 2016.

SOUZA, D. F.; MONTEIRO, A. L. G.; DITTRICH, R. L.; SCHMIDT, E. M. S.; FERNANDES, S. R.; BELTRAME, O. C. Dinâmica pré e pós colostral de parâmetros bioquímicos em cordeiros. Ciência Animal Brasileira, Goiânia, v. 15, n. 3, p. 313-321, jul./set. 2014.

STEVANOVIC, O.; STOJILJKOVIC, M.; NEDIC, D.; RADOJA, D.; NIKOLIC, V.; PRODANOVIC, R.; IVANOV, S.; VUJANAC, I. Variability of blood serum biochemical parameters in Karakachan sheep. Biotechnology in Animal Husbandry, Zemun, v. 31, n. 1, p. 55-62, jan. 2015.

TELEB, D. F.; SAIFELNASR, E. O. H.; EL-SAYED, E. H. Factors affecting performance and survivability of Saidi lambs from lambing to weaning. Egyptian Journal of Sheep and Goat Sciences, Cairo, v. 4, n. 1, p. 55-74, 2009.

THRALL, M. A.; BAKER, D. C.; CAMPBELL, T. W.; DENICOLA, D.; FETTMAN, M. J.; LASSEN, E. D.; REBAR, A.; WEISER, G. Hematologia e bioquímica clínica veterinária. São Paulo: Roca, 2007. 582 p.

TOKARNIA, C. H.; PEIXOTO, P. V.; BARBOSA, J. D.; BRITO, M. F.; DÖBEREINER, J. Deficiências minerais em animais de produção. Rio de Janeiro: Helianthus, 2010. $191 \mathrm{p}$.

VICENTE, I. S.; LEMES, J. S.; BRONDANI, W. C.; MATTEI, P.; SILVEIRA, F. A.; DEL PINO, F. A. B. Níveis metabólicos de cordeiros machos e fêmeas da raça Texel. In: SALÃO INTERNACIONAL DE ENSINO, PESQUISA E EXTENSÃO, 2., 2014, Bagé. Anais... Bagé: Universidade Federal do Pampa, 2014. v. 6, n. 2. Disponível em: <http://www.seer.unipampa.edu.br/ index.php/siepe/article/view/7932>. Acesso em: $11 \mathrm{fev}$. 2016. 
